\title{
Student's Attitude and Satisfaction towards Transformative Learning: A Research Study on Emergency Remote Learning in Tertiary Education
}

\author{
Mei Yuan Law \\ School of Education and Cognitive Science, Asia e University, Subang Jaya, Malaysia \\ Email: lawmy@rocketmail.com
}

How to cite this paper: Law, M. Y. (2021). Transformative Learning: A Research Study on Emergency Remote Learning in Tertiary Education. Creative Education, 12, 494-528. https://doi.org/10.4236/ce.2021.123035

Received: February 6, 2021

Accepted: March 2, 2021

Published: March 5, 2021

Copyright $\odot 2021$ by author(s) and Scientific Research Publishing Inc. This work is licensed under the Creative Commons Attribution International License (CC BY 4.0).

http://creativecommons.org/licenses/by/4.0/

\begin{abstract}
This study aims to discover the university student's attitude and satisfaction towards online learning during COVID-19 in Malaysia. The survey method was conducted on 97 students from a university in Kuching to understand student's attitudes and satisfaction in four major aspects; the learning materials, assessments, communications, and technological tools used and technical support in their emergency remote learning experience. The findings of this study show that most of the students have a positive attitude and satisfaction in the online learning delivery. This study revealed that relevant implications of instructional pedagogy approach and appropriate integration of technological tools can be very helpful to ensure the continuous success in delivering learning content during this COVID-19 pandemic time.
\end{abstract}

\section{Keywords}

COVID-19, Online Learning, Tertiary Education, Instructional Pedagogy, Technological Tools, Technical Support

\section{Introduction}

\subsection{Background of the Study}

The COVID-19 pandemic outbreak has plunged all the sectors of the educational field worldwide. All universities, educators, and students worldwide of the higher education sector are forced to confront the unprecedented scenarios. In response to the widespread of the COVID-19 virus, the Malaysian government has imposed a subsequent Movement Control Order (MCO) as a safety measure 
for all the citizens of the country back in March 2020. As a result of the threat posed by the COVID-19, all tertiary education in Malaysia is to transition to remote learning through a virtual setting. The closure and suspension of tertiary education face-to-face classes have interrupted the regular flow of academic programs (Jacob, Abigeal, \& Lydia, 2020). Due to the rapid shift from a face-toface educational institution to a remote learning environment, it has been a challenge for educators to convert the curriculums into a virtual learning space, with the use of instructional technology.

\subsection{The Research Problem}

The major challenge unfolded as the educators were to digitalize the curriculum and learning activities while maintaining the quality of the delivery of the learning experience among the students. As emergency remote learning is considered as a sudden shift of the instructional delivery to an online mode due to unforeseen catastrophe, the main focus for the educators is to convert the curriculum to an e-learning space rather than emphasizing on the online pedagogy (Mohmmed et al., 2020). Due to the urgency of the temporal solution towards the delivery of learning materials, the key is to provide an efficient and durable instructional delivery rather than emphasizing the building and construction of a revolutionary online learning ecosystem. Regardless of the switch, it is important to analyze and understand the attitudes and satisfaction of the students towards their learning experience based on the instructional pedagogy and technological media used, and technical support provided by educators for the delivery of the respective curriculum.

\subsection{Objectives of the Study}

The main purpose of this research study is to investigate and understand whether the instructional strategies, techniques, and technological tools used to influence the attitudes of the students towards emergency remote learning and lead to higher learning satisfaction. Through the students' attitude and level of satisfaction, research will highlight the necessary improvement and direct a better pedagogical approach on how to increase the effectiveness in online learning. The research study sought to investigate students' attitudes on four major aspects; mainly the learning curriculum, assessments, communication and interaction, as well as technological tools used and technical support in their emergency remote learning experience.

\subsection{Research Questions}

The research questions this study attempts to answer are:

1) What are the students' attitudes towards the online delivery of learning materials?

2) What are the students' attitudes towards online assessments?

3) Does online communication affect students' attitudes towards online learning? 
4) What are the students' attitudes towards use of technological tools and the technical support provided for online learning?

5) What is the students' course satisfaction towards the online learning approach?

\subsection{Significance of the Study}

Several pieces of research were made on various online learning dimensions, i.e., strategies to improve online learning, barriers, and impact of online learning in the students' academic achievements, but the least study was made on the attitude and satisfaction of students towards the effectiveness of emergency remote learning on tertiary educational level. Besides, only a few surveys include the study of students' perception of how learning curriculum and assessments, communication, and technology facilities and technical support are being conducted as a whole in online learning. The biggest limitations of these studies are generally focusing on a single academic field and most studies concentrate only on communication in the online learning environment. The lack of focus on other academic fields on a single higher education institution and least attention on the delivery of learning curriculum and assessments have become the initiative to conduct this research. The significant research gap that exists in the current literature has highlighted the importance of this research study. This comprehensive research study highlights the appropriate pedagogy and technology facilities adoption in the virtual settings of learning materials which will increase the online learning effectiveness and experience among students.

As there is an uncertain duration on the continuity of the emergency remote learning in universities due to the COVID-19 pandemic, the research study plays a significant role in determining the possible improvement or changes needed for the curriculum delivery. The students' attitude and satisfaction towards online learning help the educators to determine the appropriate execution for the course delivery not only the universities but the community across the world as students face similar problems associated with online learning during the COVID-19 and any future pandemics. This study also significantly contributes to the future management of higher education and digs the future path of online learning practices.

\section{Literature Review}

\subsection{Introduction}

The global spread of the COVID-19 pandemic has indeed led to a profound change in the education community. The pandemic has led to the closure of universities, colleges, and higher institutions around the world (Murphy, 2020). Since the primary concern for every country is to reduce the spread of the novel virus among society in general (Osman, 2020), many higher education institutions have shifted to online instruction for the continuity of learning (Weeden \& Cornwell, 2020). The education systems around the world have responded to the 
pandemic with a tremendous transition from face-to-face classes to fully online learning with "Emergency Remote Learning" protocols (Murphy, 2020).

In response to the outbreak in the country, all tertiary education institutes and universities have to reorganize and redesign the delivery of the curriculum in diverse approaches (Mohmmed et al., 2020). Effective online education requires great effort and time to build an ecosystem to support learners in both formal and informal resources. Crawford et al. (2020) has claimed that the rapid transformation into online learning has caused the facing of various obstacles and challenges. Accordingly, the preparation and development time of a fully online course takes up six to nine months before the course is delivered (Hodges et al., 2020). It will be impracticable to expect online learning to be a fully-featured or well-planned system with the given time, ranging from a few days to weeks only for online instruction and resource preparation.

In this critical period, the transition to online learning has made most of the academic institutions to focus primarily on transferring the educational content into the virtual world and not focusing specifically on online teaching and delivery methods ( $\mathrm{Wu}, 2020$ ). Thus, this research can help to determine the effectiveness and appropriateness of the pedagogy approach and utilization of technology in delivering the course curriculum. Through the students' attitude and course satisfaction tests can help to determine the essential improvement of the instructional delivery in the virtual environment. The research serves as a framework for subsequent online courses' instructional planning despite the current or another unpredictable health-threatening pandemic in the future.

\subsection{Online Learning Effectiveness}

Online learning has become an essential alternative solution for learning during the COVID-19 pandemic (Basilaia \& Kvavadze, 2020; Alipio, 2020). Many instructional communication scholars begin to examine the learning effectiveness of online courses (Kaufmann, Sellnow, \& Frisby, 2016; Kelly \& Claus, 2015; Kim, Song, \& Luo, 2016). As Sun (2016) and Bao (2020) observed, the effectiveness of online learning depends on the designed and prepared learning material as well as lecturers' engagement and interactions with the students in the online environment.

Bao (2020) proposed in one of the instructional strategies which will help students to focus and improve course effectiveness is to divide the content into smaller units. Al-Jedaiah (2020) stated that knowledge management is a necessity to receive high attention in universities which will affect the effectiveness of online learning. Some universities faced challenges in creating and exchanging knowledge with the students due to the lack of knowledge management strategies. Besides that, Teo et al. (2018) suggested that the effectiveness of e-learning can be enhanced by constructing an efficient online learning infrastructure.

Sandars et al. (2020) declared that online learning is not a single structure but rather a collection of online learning modalities and technologies. The application of technologies in education increases the accessibility to learning materials 
and resources online that meet the need for remote learning (Onyemo, 2019). Since Gupta (2018) proclaimed that one can access online learning from the portals of any universities with the use of the internet and personal media, together with the relevant pedagogy approach in delivering curriculum can establish an effective online learning experience. Most importantly, the effectiveness of online learning can be interpreted through the people's social-psychological perspective on how they experience in reality (Singh \& Hurley, 2017). To establish an effective online learning experience, it is essential to investigate the online learning environments.

\subsection{Online Learning Environments}

Online learning differs from face-to-face courses in their methods of implementation. Moreover, the creation of an effective online learning environment for online courses requires various approaches as the use of technology, content design, learning assessment, and best practices are different in online settings (Fayer, 2017). Online learning certainly involves certain pedagogical expertise with the use of digital technology, mainly related to designing better learning experiences and creating distinctive learning environments for the students (Rapanta et al., 2020). Besides that, the study indicated that instructor presence and interactive teaching style were significant determinants of the effectiveness of online learning environments (Richardson \& Swan, 2019).

\subsubsection{Features of Online Learning Environments}

As Kearns (2016) observed, the purpose of a learning environment is to engage learners and enable a meaningful knowledge construction. The flexible nature of the online learning environment provides the choice of time, place, space, and pace of study to provide a more casual atmosphere for the students to study in (Gedera, Williams, \& Wright, 2015). An online learning environment should support students the means to build their own learning space by offering flexibility to organize their learning activities according to their own pace (Damşa, Nerland, \& Andreadakis, 2019). Students have control and freedom (Northey et al., 2015) to complete the learning curriculum at their own time from any location with Internet access.

Another dominant feature of online education is that the users of digital technology and application which offer synchronous and asynchronous communication for learning. Students can take part in threaded discussion boards, blogs, learning websites, and more (Nguyen, 2015). Another recent research was done by Panigrahi et al. (2018) explained that the integration of virtual communities to online learning environments can improve learning and engagement. Besides, Degago \& Kaino (2015) and Stevens (2015) elaborated on how online learning has the potential for enhancing students' engagement during the learning process through active interaction on the online discussion boards. Interaction has both a cognitive and social function. Jeong and Hmelo-Silver (2015) indicated how digital technology can encourage collaboration by finding 
groups and communities through the sharing of resources and engagement in collaborative learning processes. Besides that, online testing has become paramount importance for a course (Clark et al., 2020). Giordano \& Christopher (2020) indicated the application of remote oral exams as an important feature for online learning which can elucidate students' thought processes through real-time communication.

\subsubsection{Challenges of Online Learning Environments}

Educators have shown concerns about the barriers that may hinder effective online learning related to both technical and pedagogical obstacles. In the relation to this study, Zhong (2020) and Crawford et al. (2020) claimed that minimal resourced institutions and limited access to technology or the internet impacted students' ability to engage and participate in the online environment. Similarly, Dutta \& Smita (2020) qualitative research also identified issues concerning online studies which include limited access to the internet, high cost of internet, unavailability of electronic devices, and students facing difficulties in using online platforms. Alvarez (2020) phenomenological research and Alipio (2020) descriptive study also supports the argument on how poor internet access, financial constraints, and lack of technological devices have been the demanding challenges among learners when exposed to emergency remote learning. Other studies by Zhang et al. (2020), Mohmmed et al. (2020) and Blizak et al. (2020) also discovered on the barrier of infrastructure and network coverage in remote areas may lead to educational inequity in online learning environments.

In addition, Adnan \& Anwar (2020) quantitative survey investigated that online learning will not be able to produce desirable results when there is a lack of face-to-face interaction and slow response time from the instructors. A study indicated that online learning is not as effective as face-to-face instruction (Pickering \& Swinnerton, 2019). Woodworth et al. (2015) mentioned that poor learning experiences might be due to poor course design and poor pedagogy in online instruction.

Apart from that, assessment is possibly the most challenging part of the transition to distance learning for an institution used to face-to-face oral or written exam, as the control shift towards the students makes it difficult to prevent students from cheating (Munoz \& Mackay, 2019). Clark et al. (2020) highlighted on how online exams have become a salient concern and are more of vulnerable to academic misconduct and technological difficulties than normal physical classes.

To effectively overcome the challenges, Mailizar et al. (2020) suggested that the students' voices and perspective on online learning are important to explore the challenges faced by students during online learning. Furthermore, Basilaia \& Kvavadze (2020) also mentioned that further research should be carried out to investigate the quality of online learning. To better understand about students' perception on quality online learning during this crisis, it is important to discover their attitudes towards learning in a virtual classroom. 


\subsection{Attitude}

\subsubsection{Learning Materials \& Assessments}

In Joseph \& Mkulu (2020) mixed-method research, they discovered that students learn more when in a shorter duration when ICT-based instruction was included. Research has demonstrated students' positive perception of the quality and clarity of the recorded lectures and e-learning materials due to the flexibility and adaptability of the faculties (Osman, 2020). However, the result from $\mathrm{Mu}$ lyanti et al. (2020) survey study showed a neutral interest in students on online learning and claimed that online learning is no more interesting than ordinary face-to-face class learning.

On the contrary, Hyseni (2020) case study discovered that students had a negative attitude towards the format of online learning, claiming that it is more difficult to acquire information. According to Ullah, Khan, \& Khan (2017) quantitative data, students indicated negative perception in understanding online learning materials without getting acquainted with appropriate guidance. Students complained about trouble finding references as the learning resources provided are limited, resulting in students gathering irrelevant information from the internet and journals (Rahiem, 2020). Lukong et al. (2020) research findings showed that students preferred face-to-face learning resulting in a better understanding of online learning lessons.

On a global scale, Aristovnik et al. (2020) have identified the amount of workload given to students on the new online curriculums. The majority of the students reported that the workload had become larger as compared to the normal face-to-face curriculum. Rahiem (2020) study also indicated students' opposing attitudes towards the extensive amount of online assignments given by the lecturer. Aristovnik et al. (2020) comprehensive study claimed on the possibility of educators being incompetent in optimizing the amount of workload due to the sudden transition to the online environment causes an increase in the students' workloads.

\subsubsection{Communication \& Interaction}

Osman (2020) claimed that the students are pleased with the online communication with the instructors as weekly online meetings were conducted using various synchronous tools like Zoom and Microsoft Teams for communication and collaborative group work. According to Aristovnik et al. (2020) large-scale quantitative study, the result showed students' appreciation with the efficient responses of the lecturers to posted questions and openness towards suggestions. Furthermore, Srinivasan (2020) study showed students' positive attitude on the use of web video conferencing technologies for engagement which established a sense of community despite some visual and audio issues.

On the other hand, students showed a negative opinion on online learning as there is a lack of direct interactions with instructors and fewer chances for discussions in a teacher-centered learning class (Hyseni, 2020). In addition, Alawamleh, Al-Twait, \& Al-Saht (2020) quantitative study discovered that the ma- 
jority of the students preferred physical face-to-face classes to online due to the low level of communication between students and instructors. Students felt that online classes are less effective due to the lack of face-to-face interaction (Gautam \& Gautam, 2020). Kamarianos et al. (2020) survey findings demonstrated negative feedback from students on the lack of communication and cooperation in which in-person communication with coworkers is preferred. This has been one of the main negative consequences of the pandemic and the following movement restriction.

\subsubsection{Technology Tools \& Technical Support}

Basilaia et al. (2020) have studied the change from face-to-face learning to online learning as an instant alternative solution amid this pandemic. They have concluded that Google applications like Google Drive, Google Classroom, Gmail, Google Docs, and more are among the effective means for online education. Aristovnik et al. (2020) global level survey concluded that students are most satisfied with real-time video conferences followed by asynchronous forms of learning delivery. During this rapid transition of learning environment, technology support is important to maximize students' online learning experience. Students are provided with initial online training and 24/7 hotline communication with the technical support team for any technical assistance (Osman, 2020). Similarly, Kamal et al. (2020) survey discovered the students' appreciation of the sufficient technical support provided by instructors for their online learning.

On the contrary, Zia (2020) quantitative findings showed that students had trouble in technology adaptability as insufficient time is given for them to familiarize themselves with the new teaching model. Although Dushkevych et al. (2020) survey indicated that learners preferred Google Meet and Moodle as the primary distance learning platforms, poor network connection and online learning platforms imperfection are among the drawbacks of virtual learning for learners.

\subsection{Satisfaction}

Esterhuyse et al. (2016) stated that online learning success is preceded by students' satisfaction which is a vital factor of the effective online learning process. To help educators understand how to improve the effectiveness of online learning, it is important to investigate variables related to learner satisfaction. For instance, Hammouri and Abu-Shanab (2018) stated that information quality and system quality have a strong influence on students' satisfaction. Relevant, sufficient, and accurate content provided can enhance students' satisfaction towards online-learning. In addition, various studies have been conducted on student satisfaction with online learning have identified that interaction and communication with students, efficient assessment of academic progress, technology, and learning environment are the important elements in establishing an effective online learning experience (Dziuban et al., 2015; Cole, Shelley, \& Swartz, 2014). In this period of pandemic crisis, it is essential to understand students' satisfaction 
towards the delivery of online curriculum and learning. The results will help educators to better understand the needs of the students especially in improving their learning experiences.

\subsection{Conclusion}

Majority of the research used quantitative measures that serve as indicators of students' attitudes towards online learning. The nature of this approach tends to only focus on closed-end questions which limited the in-depth understanding of students' thoughts and ideas. Some qualitative approach is used and very few focused on the mixed-method approach. For this research study, it is crucial to integrate a mixed method that permits a more complete and synergistic utilization of data than do separate quantitative and qualitative data collection and analysis. Other gaps from the researches include the little studies on the area of students' attitudes towards online assessments and technological media selection and support. Taken together, this study focused on an extensive exploration of students' attitudes towards the learning materials and assessments, communication, and interaction, and as well as the technology media and support incorporated in their online learning, which in return will help educators to provide a better instructional approach.

\section{Methodology}

\subsection{Research Method}

Since the purpose of this research study is to understand students' attitudes and satisfaction towards online learning during this COVID-19 pandemic period, the survey method has been selected for the data collection. The survey has been proven to be a powerful tool in gathering information especially on opinions of the people concerning different types of issues, regardless of whether it is on social, cultural, and so on. Besides that, the survey method is widely used in the educational field to understand the attitudes and perceptions of respondents. The time frame given to conduct this research study can justify the appropriateness of the selection of the survey method. Based on the nature of a survey, it can provide a quick and inexpensive means of obtaining information from a large group of people which serves as a relevant strategy for this research study.

The employment of the survey method which is divided into two broad categories; the questionnaire and the interview, shall provide an important source of knowledge and information in this mixed-method approach of the research study. Through surveys, the students' needs and expectations on online learning bring in-depth understanding for the respective instructors and educators to further improve on the instructional approaches. Thus, the data collection for both the quantitative and qualitative studies on the research topic shall be obtained through the survey method. To serve the needs of this study, the cross-sectional survey is selected to obtain an overview of attitudes and satisfaction towards online learning. A sample is then drawn from a university in town 
together with the use of questionnaires and interview techniques to collect the data. Ideally, the questionnaires were developed to collect data in the quantitative study and the interview method is employed in the qualitative study to give a detailed understanding of students' perceptions towards their online learning experience. A detailed explanation of the data collection techniques will be introduced at a later stage of this report.

\subsection{Sample Selection}

The participants of the study came from a heterogeneous composition of students registered in 2020 intake, ranging from foundation studies to bachelor's degree level of learning. The participants involved in the data collection are from a private university situated in Kuching, Sarawak, Malaysia. A non-probability sampling technique which is also known as the purposive sampling method is employed to select the participants for the research studies. The technique is also known as heterogeneous purposive sampling which enables the study to focus on a diverse range of cases especially on different courses enrolled in by students from different nationalities. Different courses most likely deployed different approaches in teaching and learning techniques which might affect students' attitudes and satisfaction in online learning during this pandemic.

Several explanations support the selection of the purposive sampling method to select the participants for this research study. The first reason was the ease of access to collect the survey data due to the COVID-19 pandemic, where all students are all off-campus and most students are currently backed to their states and countries. This situation has restricted the ease to gather the data. Secondly, the students at the university come from not only different states in Malaysia but also other countries. The diversity will help to enrich the data further. As for the third reason, students from different course programs are chosen which includes the STEM and non-STEM courses to give a broader understanding of how instructions are conducted on respective courses. Lastly, only existing students who experienced the transition from full face-to-face learning to online learning were chosen as the participants for this study as they were involved in the drastic switch for their learning experience. The opinions from this group of students were important because their opinions and answers would address exactly how the instructors delivered their learning content at a time like this.

The process of selecting and determining the size of the sample was challenging as reaching out for the respective targeted students was an issue. The availability and willingness of the target students to take part in this study are restricted as mentioned earlier. With much effort, the researcher-developed questionnaires were distributed online to all the targeted students and a total of 97 students took part in all the questionnaires. The participants varied in terms of gender, year of study, program level, academic discipline as well as current residing location. More than half of the courses which the participants were enrolled in came from STEM courses (52 participants) and the remaining was from non-STEM courses. At the same time when the survey is being distributed 
out, the students were asked whether they were willing to participate in interviews via live voice calls or video interviews. A total of 9 participants responded; 3 business major students, 3 engineering major students, 2 design students, and 1 computing student. The Consent Letter was mailed to all 97 students to inform them of the purpose of their participation in this research study.

\subsection{Data Collection Procedure}

\subsubsection{Quantitative Data Collection}

The Attitude towards Online Learning Survey and the Online Course Satisfaction Survey was distributed online to the students between $19^{\text {th }}$ October 2020 to $6^{\text {th }}$ November 2020. E-mail invitations were sent to the students, highlighting the research objectives and purposes. A copy of the consent letter was sent to every participant of the research study. It was estimated that the participants would take approximately 15 - 20 minutes to complete the two instruments.

\subsubsection{Interview Data Collection}

The interview data were collected through online voice calls and video interviews. A total of 12 students responded in the Attitude towards Online Learning Scale that they would take part in the interviews. The open-ended interview questions allow students to convey and demonstrate their opinions in their own words. Both voice calls and video interviews approach took approximately 30 minutes to gather an adequate amount of information.

\subsection{Data Analysis}

\subsubsection{Quantitative Data Analysis}

In quantitative data research, data preparation is considered the initial stage of data analysis where raw numbers are turned into meaningful data through the application of rational and critical thinking. Data validation is carried out on the collected data by selecting a random sample of the completed survey. In this research study, the survey has reached 97 respondents in total. Validations are done on 15 respondents who were randomly picked from the same university to check on their responses to a certain set of questions as to prevent bad data from slipping into the data set. Moreover, basic data checks and identifying any data points that may affect the accuracy of the results is conducted. During the editing process, responses from the participants are checked to ensure all fields in the questionnaire were answered. The next process includes data coding of the collected data. Respective groupings and values were assigned to various responses from the survey.

This research study focuses on descriptive analysis for both the researcher-developed Attitude towards Online Learning Survey and the researcher-developed Online Course Satisfaction Survey. The data analysis summarized the data and direct patterns towards the findings for all five research questions. Descriptive statistics are helpful for this research study as the sample data is limited but sufficient enough to provide an overview of how students respond through 
their attitude and satisfaction. However, the data do not explain the rationale or reasons behind those numbers. Therefore, qualitative data analysis is implemented in this mixed-method approach to have a thorough understanding of the research topic.

\subsubsection{Qualitative Data Analysis}

These findings are used to provide a rich understanding of learners that cannot be obtained through the Likert scales used in quantitative studies. The content analysis method is chosen to analyze the documented information in the form of texts and media. This method is relevant for this research study as it can highlight the in-depth responses and attitudes of the students towards the research questions. To begin the data analysis, the data are first being run through several times to get familiar with it. Data from the online voice call interview and live video interview through Zoom are then transcribed. The research objectives are being revisited which helps to identify the questions that can be answered through the collected data.

The next step involves the development of a framework in which coding is technique is applied. The coding process is done to categorize the data collected. Unlike quantitative methods, qualitative data analysis requires the analytical and critical thinking skills of the researcher. A list of themes was first identified and generated by using a word or short phrases which represents an idea from the research questions. One of the most effective methods of data interpretation used for this study is the word and phrase repetitions. The scanning of primary data for words and phrases which are most commonly used by the respondents helps to form and identify the pattern and relationships. The participants' statements were then coded and nested under the appropriate themes. Once all statements were grouped in an organized manner, statements within each theme were grouped into sub-categories. Finally, patterns and relationships between themes and each sub-category were further examined for findings that will answer the research questions and finding areas.

\section{Results}

\subsection{Introduction}

The research study aims to understand students' attitudes and satisfaction towards emergency online due to the COVID-19 pandemic. To meet the purpose, the survey research method is used to investigate and collect a total of $97 \mathrm{stu}-$ dents' attitudes towards learning in a virtual environment. Since the study applied a mixed-method approach for the data collection, 97 participants are involved in answering the questionnaire surveys for both Attitude towards Online Learning Survey and Online Learning Satisfaction Survey. Interviews are being conducted on 9 students of the same group of samples to obtain a comprehensive understanding of the research findings. A recap on the research questions this study attempts to answer are as follows: 
1) What are the students' attitudes towards the online delivery of learning materials?

2) What are the students' attitudes towards online assessments?

3) Does online communication affect students' attitudes towards online learning?

4) What are the students' attitudes towards the use of technological tools and the technical support provided for online learning?

5) What is the students' course satisfaction towards the online learning approach?

The results of the study are organized by presenting the demographic data of the students, followed by the quantitative data and qualitative data. The results information is grouped accordingly to answer each research question.

\subsection{Demographic Data}

There are a total of 97 students completing the survey questionnaires. The full demographic data are broken down by categories in Table 1 . The data shows a

Table 1. Demographic Information of students $(\mathrm{N}=97)$.

\begin{tabular}{|c|c|c|}
\hline Variables & Frequency & Percentage (\%) \\
\hline \multicolumn{3}{|l|}{ Gender } \\
\hline Male & 58 & 59.8 \\
\hline Female & 39 & 40.2 \\
\hline \multicolumn{3}{|l|}{ Year of Study } \\
\hline Year 1 & 20 & 20.6 \\
\hline Year 2 & 62 & 63.0 \\
\hline Year 3 & 12 & 12.4 \\
\hline Year 4 & 3 & 3.1 \\
\hline \multicolumn{3}{|l|}{ Academic Major } \\
\hline Engineering & 38 & 39.2 \\
\hline Computing & 11 & 11.3 \\
\hline Design & 14 & 14.4 \\
\hline Business & 31 & 32 \\
\hline Science & 3 & 3.1 \\
\hline Art \& Education & 0 & 0 \\
\hline \multicolumn{3}{|l|}{ Program Level } \\
\hline Foundation & 13 & 13.4 \\
\hline Diploma & 0 & 0 \\
\hline Degree & 84 & 86.6 \\
\hline Postgraduate Certificate & 0 & 0 \\
\hline \multicolumn{3}{|l|}{ Current Residing Location } \\
\hline Malaysia & 89 & 91.8 \\
\hline Outside Malaysia & 8 & 8.2 \\
\hline
\end{tabular}


fair distribution of male (59.8\%) and female (40.2\%) ratio with a high number of Year 2 students (63.9\%). The results show that there are two key academic majors the students are taking, the Engineering course (39.2\%) and the Business course (32\%), followed by the Design course (14.4\%), Computing course (11.3\%) and Science course (3\%). The data results display a large amount of Degree Level students (86.6\%), and a heavy concentration of local students (91.8\%).

\subsection{Result Findings}

Research Question 1: What are the students' attitudes towards the online delivery of learning materials?

In order to answer the research question, a descriptive statistic was used to present the data gathered from the sub-scale, Learning Materials, of the Attitude towards Online Learning Survey. Table 2 shows that students had the highest mean score for Item 5: Instructors have provided sufficient and informative learning materials $(\mathrm{M}=4.37, \mathrm{SD}=3.87$ ), with $37.1 \%$ Strongly Agree and $62.9 \%$ Agree. The second highest mean score is Item 3: The learning materials prepared can fulfill the needs of my studies $(\mathrm{M}=4.31, \mathrm{SD}=3.82)$, with a total number of $35.1 \%$ Strongly Agree, $60.8 \%$ Agree, and $4.1 \%$ in Neutral. The next highest mean score is Item 1: The learning materials are well-organized and navigated $(\mathrm{M}=$ 4.12 , SD $=3.61$ ), with $17.5 \%$ Strongly Agree, $77.3 \%$ Agree, and 5\% Neutral. The following mean score is Item 4 : I can understand the information provided with minimal guidance from my instructors $(\mathrm{M}=4.08, \mathrm{SD}=3.60)$, with $20.6 \%$ Strongly Agree, 70.1\% Agree, 6.2\% Neutral and 3.1\% Disagree; and the least mean score is for Item 2: I can easily access all the learning materials anytime and anywhere $(\mathrm{M}=4.06, \mathrm{SD}=3.56)$, with $13.4 \%$ Strongly Agree, $80.4 \%$ Agree, $5.2 \%$ being Neutral and 1\% Disagree.

Table 2. Students' attitude on learning materials.

\begin{tabular}{|c|c|c|c|c|c|c|c|}
\hline Item & SA & A & $\mathrm{N}$ & $\mathrm{D}$ & $\mathrm{SD}$ & Mean & $\begin{array}{l}\text { Standard } \\
\text { Deviation }\end{array}$ \\
\hline $\begin{array}{l}\text { 1. The learning materials are } \\
\text { well-organized and navigated. }\end{array}$ & $17.5 \%$ & $77.3 \%$ & $5.0 \%$ & $0 \%$ & $0 \%$ & 4.12 & 3.62 \\
\hline $\begin{array}{l}\text { 2. I can easily access all the learning } \\
\text { materials anytime and anywhere. }\end{array}$ & $13.4 \%$ & $80.4 \%$ & $5.2 \%$ & $1.0 \%$ & $0 \%$ & 4.06 & 3.56 \\
\hline $\begin{array}{l}\text { 3. The learning materials prepared } \\
\text { can fulfill the needs of my studies. }\end{array}$ & $35.1 \%$ & $60.8 \%$ & $4.1 \%$ & $0 \%$ & $0 \%$ & 4.31 & 3.82 \\
\hline $\begin{array}{l}\text { 4. I can understand the information } \\
\text { provided with minimal guidance } \\
\text { from my instructors. }\end{array}$ & $20.6 \%$ & $70.1 \%$ & $6.2 \%$ & $3.1 \%$ & $0 \%$ & 4.08 & 3.60 \\
\hline $\begin{array}{l}\text { 5. Instructors have provided sufficient } \\
\text { and informative learning materials. }\end{array}$ & $37.1 \%$ & $62.9 \%$ & $0 \%$ & $0 \%$ & $0 \%$ & 4.37 & 3.87 \\
\hline $\begin{array}{r}\text { Codes: } 5 \text { (Strongly Agree }=\text { SA) } \\
1 \mathrm{~S}\end{array}$ & $\begin{array}{l}\text { (Agree } \\
\text { ngly Di }\end{array}$ & $\begin{array}{l}\mathrm{A}), 3(\mathrm{I} \\
\text { agree }=\mathrm{s}\end{array}$ & $\begin{array}{l}\text { Jeutral } \\
\text { D }\end{array}$ & $=\mathrm{N})$, & (Dis & gree $=\mathrm{I}$ & \\
\hline
\end{tabular}


The data retrieved from the interviews showed a comprehensive understanding of students' attitudes on how the learning materials being delivered online and will the method facilitates their learning. The following is the report of the data analysis based upon interviews. Statements by all students indicated that the learning materials including lecture slides, reading materials, and tutorial videos are included in the learning portal. Other extra learning materials related to the learning topic are directed with external links to the respective videos or websites. A business major student stated, "Apart from videos, slides, and articles, my lecturer also provided us some audiobook or podcasts which gives me an extensive understanding of my learning topics".

Most students expressed their positive attitudes towards the way of delivery. A computing major student mentioned, "I like how it is delivered online especially in videos format as I can pause to catch up on the information and steps of writing the codes," while another student mentioned, "Pre-recorded tutorial videos help me a lot as I can watch them over and over again". One student also stated, "I like how my lecturer took the effort to record and explain the topics thoroughly which I prefer as compared to the external video links that are boring to watch. It is easily understandable and interactive even in recorded video format by my lecturer". An engineering major student stated, "As for reading materials, they are helpful when it comes to theoretical explanations like formulas and calculations". Many students believe that the sufficient and appropriate information is provided which do fulfill their learning needs. Business major students expressed, "I like how everything is being placed online in Canvas where information is at the tip of my hands which I can refer to anytime and anywhere," and "It does help me a lot as I do not have to spend countless hours to research for inappropriate information".

Some students showed concern about how the way of learning delivery is being conducted can help in their learning. For example, one student stated, "I believe videos do help my learning but at the same time I think it depends on how engaging or interesting the way information is delivered. Some are just too boring to watch till the end." Another engineering major student also mentioned, "However, I must admit that it is rather boring to watch some videos from the external source although they are informative". One student further pointed out, "Although online delivery does provide the information and learning materials, it is hard to motivate me to make the effort to watch a full 45 -minute tutorial video most of the time".

Research Question 2: What are the students' attitudes towards online assessments?

To answer the research question, the descriptive statistic was used to present the data gathered from the sub-scale, Assessments, of the Attitude towards Online Learning Survey. Table 3 shows that students had the highest mean score for Item 4: I feel that online assessments are more effective and comfortable as compared to proctored exams $(\mathrm{M}=4.58, \mathrm{SD}=4.08)$, with $57.7 \%$ Strongly Agree and $42.3 \%$ Agree. The second highest mean score is Item 5: I like how organized 
Table 3. Students' attitude on assessments.

\begin{tabular}{|c|c|c|c|c|c|c|c|}
\hline Item & SA & A & $\mathrm{N}$ & D & SD & Mean & $\begin{array}{l}\text { Standard } \\
\text { Deviation }\end{array}$ \\
\hline $\begin{array}{l}\text { 1. I believe the workload given is } \\
\text { appropriate. }\end{array}$ & $21.6 \%$ & $75.3 \%$ & $3.1 \%$ & $0 \%$ & $0 \%$ & 4.19 & 3.68 \\
\hline $\begin{array}{l}\text { 2. I believe that the assignments are } \\
\text { relevant and useful for my course. }\end{array}$ & $21.6 \%$ & $72.2 \%$ & $6.2 \%$ & $0 \%$ & $0 \%$ & 4.15 & 3.66 \\
\hline $\begin{array}{l}\text { 3. I can keep track of and manage my } \\
\text { assessments as they are well organized. }\end{array}$ & $14.4 \%$ & $72.2 \%$ & $9.3 \%$ & $4.1 \%$ & $0 \%$ & 3.97 & 3.49 \\
\hline $\begin{array}{l}\text { 4. I feel that online assessments are } \\
\text { more effective and comfortable as } \\
\text { compared to proctored exams. }\end{array}$ & $57.7 \%$ & $42.3 \%$ & $0 \%$ & $0 \%$ & $0 \%$ & 4.58 & 4.08 \\
\hline $\begin{array}{l}\text { 5. I like how organized the information } \\
\text { and requirements of the online } \\
\text { assessments being delivered. }\end{array}$ & $41.2 \%$ & $54.6 \%$ & $4.2 \%$ & $0 \%$ & $0 \%$ & 4.37 & 3.88 \\
\hline Codes: $5($ Strongly Agree $=$ SA $)$ & $\begin{array}{l}\text { (Agree } \\
\text { ngly D }\end{array}$ & $\begin{array}{l}=\text { A), } 3 \\
\text { agree }=\end{array}$ & $\begin{array}{l}\text { leutr } \\
D\end{array}$ & $=\mathrm{N})$, & & ree & \\
\hline
\end{tabular}

the information and requirements of the online assessments being delivered ( $M$ $=4.37, \mathrm{SD}=3.88)$, with a total number of $41.2 \%$ Strongly Agree, $54.6 \%$ Agree, and $4.2 \%$ Neutral. The following highest mean score is Item 1: I believe the workload given is appropriate $(\mathrm{M}=4.19, \mathrm{SD}=3.68)$, with $21.6 \%$ Strongly Agree, 75.3\% Agree and $3.1 \%$ being Neutral. The second least mean score is Item 2: I believe that the assignments are relevant and useful for my course $(\mathrm{M}=4.15, \mathrm{SD}$ = 3.66), with 21.6\% Strongly Agree, 72.2\% Agree, and 6.2\% Neutral. Lastly, the least mean score is for Item 3: I can keep track of and manage my assessments as they are well organized $(\mathrm{M}=3.97, \mathrm{SD}=3.49)$, with $13.4 \%$ Strongly Agree, $80.4 \%$ Agree, 5.2\% being Neutral and 1\% Disagree.

From the data collected, students mentioned that online projects and assignments are some common practice which they had even without the online learning while experiencing a change in exams. Students' thoughts and experiences are elaborated in the following statements based on the report of the data analysis of the interviews.

The majority of the students showed a positive attitude on online projects and assignments. Many mentioned that one of the differences for fully online projects and assignments are the removal of physical or hardcopy submissions. As a student indicated, "It saves me the time to printed and submit an extra hardcopy of my assignment". One student stated, "Online assignments are actually helpful and motivating for me. As multiple small tasks are given throughout the semester, I can constantly be keeping myself motivated and efficient in completing my tasks." Another student added, "The flexibility of online projects has become a plus point for me where I can manage it on my own pace".

All students who had exams showed positive preferences in the new open book exam approach. An engineering major student mentioned, "Since physical exams are canceled, I've come to prefer the open book assessments as we are 
given more flexibility in approaching the questions". Another student mentioned that the online exam is very convenient. The student stated, "I can save my traveling time to campus just to sit for an exam since everything is now online". An engineering major student added, "I feel less stressful with online open book test as compared to the proctored exams as I don't have to do so much memorizing for the context".

Students did express their concerns and missing elements about online projects, assignments, and exams. A student mentioned, "If there are group related assignments, they can be a little concerning as it's hard to communicate and reach out for my teammates sometimes. At least in a physical class, we can have face-to-face discussion and meetings". Students also expressed how they feel about online presentation. As a student stated, "Online presentation felt rather unnatural to me" and another student added, "I prefer to have a physical presence in which can I interact with the audiences face-to-face". A design major student further elaborated: "One must have a good internet connection to be able to present online successfully". The student did raise the concern of openbook exams as reflected in the statement, "It is a way for students to "cheat" and make references".

Research Question 3: Does online communication affect students' attitudes towards online learning?

Descriptive data were used to explain the data collected for the sub-scale, Online Communication, of the Attitude towards Online Learning Survey. Table 4 indicates that students had the highest mean score for Item 3: I can reach out to my instructors online and receive sufficient feedback and response $(M=4.42$, SD $=3.93$ ), with $45.5 \%$ Strongly Agree and 51.5\% Agree and 3.1\% in Neutral rating. The second highest mean score is Item 2: I like the flexibility of online communication with my peers and instructors $(\mathrm{M}=4.36, \mathrm{SD}=3.86)$, with a total number of 38.1\% Strongly Agree, 59.8\% Agree, and 2.1\% Neutral. The next highest mean score is Item 4: I feel comfortable communicating online with my instructors $(\mathrm{M}=4.35, \mathrm{SD}=3.85)$, with 35.1\% Strongly Agree and 64.9\% Agree. The second least mean score is Item 5: I believe that online communication has made the learning process more effective than a regular face-to-face class $(\mathrm{M}=$ 4.12, SD = 3.63), with 21.6\% Strongly Agree, 69.1\% Agree, and 9.3\% Neutral. The item with the least mean score is for Item 1: I have become more interactive and participative in online discussions than in physical classes $(\mathrm{M}=3.79, \mathrm{SD}=$ 3.36), with $18.6 \%$ Strongly Agree, 51.5\% Agree, 20.6\% being Neutral and 9.3\% Disagree in rating.

To answer the question, the data retrieved from the interviews showed the types of communication platforms students used and their thoughts on the usefulness of the respective online communication towards their learning. The following is the report of the data analysis based upon interviews addressing the online communications platforms used and how it supports students in their learning. 
Table 4. Students' attitude on online communication.

\begin{tabular}{|c|c|c|c|c|c|c|c|}
\hline Item & SA & A & $\mathrm{N}$ & D & SD & Mean & $\begin{array}{l}\text { Standard } \\
\text { Deviation }\end{array}$ \\
\hline $\begin{array}{l}\text { 1. I have become more interactive and } \\
\text { participative in online discussions than } \\
\text { in physical classes. }\end{array}$ & $18.6 \%$ & $51.5 \%$ & $20.6 \%$ & $9.3 \%$ & $0 \%$ & 3.79 & 3.36 \\
\hline $\begin{array}{l}\text { 2. I like the flexibility of online } \\
\text { communication with my peers and } \\
\text { instructors. }\end{array}$ & $38.1 \%$ & $59.8 \%$ & $2.1 \%$ & $0 \%$ & $0 \%$ & 4.36 & 3.86 \\
\hline $\begin{array}{l}\text { 3. I can reach out to my instructors } \\
\text { online and receive sufficient feedback } \\
\text { and response. }\end{array}$ & $45.4 \%$ & $51.5 \%$ & $3.1 \%$ & $0 \%$ & $0 \%$ & 4.42 & 3.93 \\
\hline $\begin{array}{l}\text { 4. I feel comfortable communicating } \\
\text { online with my instructors. }\end{array}$ & $35.1 \%$ & $64.9 \%$ & $0 \%$ & $0 \%$ & $0 \%$ & 4.35 & 3.85 \\
\hline $\begin{array}{l}\text { 5. I believe that online communication } \\
\text { has made the learning process more } \\
\text { effective than a regular face-to-face } \\
\text { class. }\end{array}$ & $21.6 \%$ & $69.1 \%$ & $9.3 \%$ & $0 \%$ & $0 \%$ & 4.12 & 3.63 \\
\hline Codes: 5 (Strongly Agree $=$ SA & $\begin{array}{l}\text { (Agre } \\
\text { agly D }\end{array}$ & $\begin{array}{l}\text { A), } 3(1 \\
\text { gree }=\end{array}$ & $\begin{array}{l}\text { Neutral } \\
\text { SD }\end{array}$ & $=\mathrm{N})$, & & ree $=$ & \\
\hline
\end{tabular}

All students mentioned that Microsoft Teams and Zoom are the two common online live interactive platforms being used for their online learning. As a student stated, "We used a lot the Microsoft Teams for live tutorial and lecture classes apart from video recordings where we can have live interactions with peers and lecturers". Another student added, "I use Microsoft Teams all the time for my online group discussion where we can do voice discussion in real-time". Students expressed their appreciation for the real-time communication and interaction they can have through Microsoft Teams, as an engineering major student mentioned, "It is equally effective for me to achieve my learning needs if were to compare with physical face-to-face meeting since we get to gather virtually have a real-time conversation with our peers". A business major student also stated, "I love the real-time chatting session and voice call with lecturers and classmates in Microsoft Teams as I can get instant answers and clarification for my learning topics".

They further added that Outlook is the go for email platform to consult with their lecturers on study matters. One student stated; "I use a lot of emailing in Outlook when I wanted to have clarifications on topics with my lecturers. It is a form of formality to me" and another added, "I use email for any clarification with my lecturer outside class hour". Another student mentioned, "I use the Canvas email system to reach out for my lecturer all the time". Apart from the emailing platform, some students mentioned using other online communication platforms and applications like WhatsApp, Facebook Messanger, Discord, and even Reddit. One student stated, "I do use Messenger and WhatsApp to chat with friends outside a class hour for assignments discussion". From the inter- 
view findings, only students from both design and computing faculty indicated the use of Discord and Reddit as a form of online communication for their learning. A design student stated, "I joined Discord groups to chat and learn from the design community which helps me to gain extra knowledge on my learning topics". The computing major student said, "I found several coding Discord groups online where I get to hang out and learn from people of the same community about software design. I also follow some software design related Subreddits which I can join in the discussion related to my learning".

There are additional findings from the data analysis in which students raised the uncertainty of why certain forms of online communication are not used. A design student stated, “I don't know about other faculty but we don't use much of the Canvas discussion forum for our learning. Only a few threads sharing session can be found". Another student from the business faculty mentioned, "Sadly there is no one out there forming a study group on Facebook or somewhere online where individuals can expand their learning with others of the same course within the University. Otherwise, I can learn even more".

Research Question 4: What are the students' attitudes towards use of technological tools and the technical support provided for online learning?

Descriptive data explains the results collected for the sub-scale, Online Communication, of the Attitude towards Online Learning Survey. Table 5 demonstrates that students had the highest mean score for Item 1: A variety of media and digital tools used by instructors has made online learning more exciting and effective $(\mathrm{M}=4.39, \mathrm{SD}=3.90)$, with $44.3 \%$ Strongly Agree and 50.5\% Agree and $5.2 \%$ in Neutral. The second highest mean score is Item 4: I can reach out to my instructors and receive assistance on technical difficulties in accessing course materials $(\mathrm{M}=4.36, \mathrm{SD}=3.87)$, with a total number of $42.3 \%$ Strongly Agree, $51.5 \%$ Agree, and $6.2 \%$ in Neutral rating. The third highest mean score is Item 2: I like the real-time learning sessions with instructors and peers through live streams $(\mathrm{M}=4.22, \mathrm{SD}=3.75)$, with $36.1 \%$ Strongly Agree and $52.6 \%$ Agree, 8.2\% Neutral and 3.1\% Disagree. The following mean score is Item 3: I can easily adapt to the new online teaching method with technology integration $(M=4.19$, SD $=3.70$ ), with $29.9 \%$ Strongly Agree, 58.8\% Agree, and 11.3\% Neutral rating. The item with the least mean score is for Item 5: I receive help in problems related to the information systems from the institution's IT department $(M=3.80$, SD $=3.37$ ), with $21.6 \%$ Strongly Agree, $42.3 \%$ Agree, $30.9 \%$ being Neutral and $5.2 \%$ Disagree in rating.

From the data analysis of the interviews, most of the students elaborated on how video technology beneficial to their studies and also their concerns on this technological approach. Besides that, students from different academic majors elaborated on what are their thoughts on certain technologies used by instructors in their online learning. Students also indicated the support received whenever encountering technical issues. The following shows a comprehensive explanation from the students gathered from the interviews. 
Table 5. Students' attitude on technological tools and technical support.

\begin{tabular}{|c|c|c|c|c|c|c|c|}
\hline Item & SA & A & $\mathrm{N}$ & D & SD & Mean & $\begin{array}{l}\text { Standard } \\
\text { Deviation }\end{array}$ \\
\hline $\begin{array}{l}\text { 1. A variety of media and digital tools } \\
\text { used by instructors has made online } \\
\text { learning more exciting and effective. }\end{array}$ & $44.3 \%$ & $50.5 \%$ & $5.2 \%$ & $0 \%$ & $0 \%$ & 4.39 & 3.90 \\
\hline $\begin{array}{l}\text { 2. I like the real-time learning sessions } \\
\text { with instructors and peers through live } \\
\text { streams. }\end{array}$ & $36.1 \%$ & $52.6 \%$ & $8.2 \%$ & $3.1 \%$ & $0 \%$ & 4.22 & 3.75 \\
\hline $\begin{array}{l}\text { 3. I can easily adapt to the new online } \\
\text { teaching method with technology } \\
\text { integration. }\end{array}$ & $29.9 \%$ & $58.8 \%$ & $11.3 \%$ & $0 \%$ & $0 \%$ & 4.19 & 3.70 \\
\hline $\begin{array}{l}\text { 4. I can reach out to my instructors and } \\
\text { receive assistance on technical } \\
\text { difficulties in accessing course materials. }\end{array}$ & $42.3 \%$ & $51.5 \%$ & $6.2 \%$ & $0 \%$ & $0 \%$ & 4.36 & 3.87 \\
\hline $\begin{array}{l}\text { 5. I receive help in problems related to } \\
\text { the information systems from the } \\
\text { institution's IT department. }\end{array}$ & $21.6 \%$ & $42.3 \%$ & $30.9 \%$ & $5.2 \%$ & $0 \%$ & 3.80 & 3.37 \\
\hline $\begin{array}{r}\text { Codes: } 5(\text { Strongly Agree }=\text { SA }) \\
1 \mathrm{~S}\end{array}$ & $\begin{array}{l}\text { Agre } \\
\text { gly D }\end{array}$ & $\begin{array}{l}\text { A), } \\
\text { gree }\end{array}$ & $\begin{array}{l}\text { Neut } \\
\text { SD }\end{array}$ & $=\mathrm{N}$ ) & & ree $=\mathrm{I}$ & \\
\hline
\end{tabular}

The majority of the students showed a positive attitude on how the video technology used in delivering the course materials turned out to be beneficial in their learning. One student stated, "At first I was so worried about how bad my learning experience will be affected when we switched to fully online learning. I was surprised at how both broadcasting and recorded videos can continue to deliver and continue to facilitate my learning, just like what it is in physical classes". Another student further added, "The live stream classes open up the opportunity for students to engage with instructors in real-time where instant clarification and answers are given by lecturers".

A few students brought up their concern on the video technology approach. As one student mentioned, "When it comes to live session classes, it is a little troublesome for some students if they have a poor internet connection. The live stream ended up being lagging and buffers a lot which in return I might miss out some important message or points from the lecturer". A student indicated, "Sometimes the unstable internet happens on our lecturers' end and that interferes with our live class session a little" while another student added, "I experience some terrible sound output from the end of our lectures. It is challenging to get the proper wordings and it tends to get annoying especially for longer live sessions".

Only students with engineering major emphasized heavily on the use of simulations practice for their lab classes as reflected in the statement, "Our lecturers introduce simulation program for our laboratory exercise since we can't do it physically. I like it since it's more accurate." Another student further added, "No natural errors are occurring in the simulation process, unlike physical experi- 
ment where there are a lot of natural factors we need to consider". On the other hand, both business and computing students mentioned the use of the Kahoot program. A business student stated, "Our lecturer uses Kahoot in for our tutorial classes where we can engage with quizzes. It does make the learning experience interesting". The computing major student added, "The game-like feel software keeps the learning process more engaging for me". The design student mentioned the introduction of Google Art \& Culture by the lecturer where virtual tour and field trips to different museums are made possible.

All students mentioned that they will first approach their lecturers on any technical errors in accessing their learning materials or content in Canvas. A student stated, "This is one of the most important kinds of support I expect to get in the online class from lecturers. The support I received is effective and access error matter is resolved". Besides accessing learning materials on Canvas, one student mentioned the technical troubles to join live classes and how the lecturer helped in this condition. The student added, "I informed my lecturers about the poor internet connection of mind to join live sessions, and so they recorded all the live sessions just for students like me to playback the content anytime". Another student further elaborated, "If I encounter anything beyond what my lecturer can resolve, I will reach out for the IT department to handle the issues".

Research Question 5: What is the students' course satisfaction towards the online learning approach?

Table 6 reveals the descriptive data of students' course satisfaction on online learning which answers the research question. In response to online course satisfaction-based questions, more than three-quarters of total students (89.7\%) are satisfied with the course materials provided while $10.3 \%$ stayed neutral. A high number of university students (94.8\%) showed satisfaction with the course activities and 5.2\% showed a neutral response. $94.8 \%$ are pleased with the workload assigned for their respective courses while 5.2\% remained neutral; $41.25 \%$ of students are well pleased with the assessment methods for their online learning. All students showed positive satisfaction on the interaction between the instructors, with $37.1 \%$ Strongly Agree and 62.9\% Agree on the item. More than two-thirds of the students $(70.1 \%)$ are satisfied with the online communication between classmates, $23.7 \%$ stayed neutral, and $6.2 \%$ showed dissatisfaction.

Students displayed satisfaction (96.9\%) with the technologies being used like live streaming, video, and audio materials while $3.1 \%$ of students remained neutral. $24.7 \%$ of students showed high satisfaction and the remaining $75.3 \%$ of students displayed their satisfaction with the course management system. A total of $80.4 \%$ of students are satisfied with the technical support provided, $17.5 \%$ showed neutral responses, and $2.1 \%$ displayed dissatisfaction. $93.8 \%$ of students are satisfied with online learning in which they would prefer if was given the choice to chose between face-to-face learning, and $6.2 \%$ of students showed neutral responses. $95.9 \%$ of students showed satisfactions while $4.1 \%$ remained 
Table 6. Students' online course satisfaction.

\begin{tabular}{|c|c|c|c|c|c|c|c|}
\hline Item & SA & A & $\mathrm{N}$ & $\mathrm{D}$ & SD & Mean & $\begin{array}{l}\text { Standard } \\
\text { Deviation }\end{array}$ \\
\hline 1. I am satisfied with the course materials. & $28.9 \%$ & $60.8 \%$ & $10.3 \%$ & $0 \%$ & $0 \%$ & 4.19 & 3.70 \\
\hline 2. I am satisfied with the course activities. & $29.2 \%$ & $64.9 \%$ & $5.2 \%$ & $0 \%$ & $0 \%$ & 4.25 & 3.75 \\
\hline $\begin{array}{l}\text { 3. I am satisfied with the workload } \\
\text { assigned. }\end{array}$ & $23.7 \%$ & $71.1 \%$ & $5.2 \%$ & $0 \%$ & $0 \%$ & 4.19 & 3.69 \\
\hline $\begin{array}{l}\text { 4. I am satisfied with the assessment } \\
\text { methods. }\end{array}$ & $41.2 \%$ & $58.8 \%$ & $0 \%$ & $0 \%$ & $0 \%$ & 4.41 & 3.91 \\
\hline $\begin{array}{l}\text { 5. I am satisfied with the interaction } \\
\text { between the instructors. }\end{array}$ & $37.1 \%$ & $62.9 \%$ & $0 \%$ & $0 \%$ & $0 \%$ & 4.37 & 3.87 \\
\hline $\begin{array}{l}\text { 6. I am satisfied with the online } \\
\text { communication between my classmates. }\end{array}$ & $20.6 \%$ & $49.5 \%$ & $23.7 \%$ & $6.2 \%$ & $0 \%$ & 3.85 & 3.41 \\
\hline $\begin{array}{l}\text { 7. I am satisfied with the technologies } \\
\text { being used (live streaming, video, audio } \\
\text { materials). }\end{array}$ & $30.9 \%$ & $66.0 \%$ & $3.1 \%$ & $0 \%$ & $0 \%$ & 4.28 & 3.78 \\
\hline $\begin{array}{l}\text { 8. I am satisfied with the course } \\
\text { management system. }\end{array}$ & $24.7 \%$ & $75.3 \%$ & $0 \%$ & $0 \%$ & $0 \%$ & 4.25 & 3.74 \\
\hline $\begin{array}{l}\text { 9. I am satisfied with the technical support } \\
\text { provided. }\end{array}$ & $19.6 \%$ & $60.8 \%$ & $17.5 \%$ & $2.1 \%$ & $0 \%$ & 3.98 & 3.51 \\
\hline $\begin{array}{l}\text { 10. If I had a choice, I would choose } \\
\text { online learning over face-to-face classes } \\
\text { for this course. }\end{array}$ & $23.7 \%$ & $70.1 \%$ & $6.2 \%$ & $0 \%$ & $0 \%$ & 4.18 & 3.68 \\
\hline $\begin{array}{l}\text { 11. Overall, the online course has } \\
\text { effectively presented the desire learning } \\
\text { outcome. }\end{array}$ & $23.7 \%$ & $72.2 \%$ & $4.1 \%$ & $0 \%$ & $0 \%$ & 4.20 & 3.69 \\
\hline $\begin{array}{l}\text { 12. Overall, I am satisfied with the online } \\
\text { learning course. }\end{array}$ & $15.5 \%$ & $76.3 \%$ & $8.2 \%$ & $0 \%$ & $0 \%$ & 4.07 & 3.57 \\
\hline $\begin{array}{r}\text { Codes: } 5 \text { (Strongly Agree }=\text { SA }), 4( \\
1 \text { Stron }\end{array}$ & $\begin{array}{l}\text { ree }= \\
\text { Disag }\end{array}$ & $\begin{array}{l}\text { A), } 3(1 \\
\text { ree }=\end{array}$ & eutra & & & p & \\
\hline
\end{tabular}

neutral on an online course as the desire learning outcomes were effectively presented. Overall, the majority of the students $(91.8 \%)$ were satisfied with the online learning course.

The data analysis from the interview illustrated the students' satisfaction with online learning. The following statements showed the students' preferences in the mode of learning and the reason for their choice.

The majority of the students are satisfied with the switch from face-to-face classes to a fully online course delivery due to the convenience in time management. A business major student mentioned, "I am satisfied with online classes than face-to-face as it offers more flexibility in time" while another student added, "Online learning saves up my traveling time to campus completely". The computing major student further elaborated, "I can wake up later or at least near the start of the class".

Students also mentioned other benefits and reasons why they are satisfied 
with online learning and preferred this mode of learning. A business major student stated, "It is so much quieter in virtual class and it is suitable for me to concentrate. I remember during face-to-face lecture classes where students tend to make noises and interfere with my concentration during lessons". Design students expressed their satisfaction with online learning as reflected in the statements, "I can submit and take part in activities with one click of the button" and "It is very convenient for me as a design student in which I can learn and do all assignments from my computer without having to be present for physical classes". An engineering major student stated, "I like how the laboratory work is being conducted through simulation programs as it is more precise and accurate for my learning. We do not have simulations during physical face-to-face lessons".

There are several students who brought up their concerns and are less satisfied with certain aspects of online study. All the students who are less satisfied with online studies mentioned the internet connection. One student indicated, "I have a bad internet connection and I can't participate in some live class activities" while another revealed, "I too have poor internet and it is frustrating at times to constantly reconnecting myself during live broadcast lessons". Moreover, a student stated, "I am way less productive as compared to attending a physical class. I can't motivate myself to work hard and I get distracted easily at home". Another student added, "I missed the physical meet-up and interaction with peers and lecturers on campus. It just doesn't feel the same in a virtual setting".

\section{Discussion}

\subsection{Introduction}

The COVID-19 pandemic has caused a major challenge in which the curriculum and learning activities are to be shifted online while maintaining the quality of the delivery of the learning experience among the students in tertiary education. Therefore, the objectives of this research study are to investigate and understand whether the instructional strategies and technological tools used to influence the attitudes of the students towards emergency remote learning and lead to higher learning satisfaction. This chapter discusses the summary findings of the specific research questions and connects to the findings with existing research studies. The discussion section also covers the possible reasons for achieving certain outcomes in this study and the feasible implications of the study findings for professional practice. Finally, recommendations for future research are presented. The details are as follows. This study addressed the following questions:

1) What are the students' attitudes towards the online delivery of learning materials?

2) What are the students' attitudes towards online assessments?

3) Does online communication affect students' attitudes towards online learning? 
4) What are the students' attitudes towards the use of technological tools and the technical support provided for online learning?

5) What is the students' course satisfaction towards the online learning approach?

\subsection{Discussion}

\subsubsection{Learning Materials}

The high positive attitudes from the students on the learning materials may be because students experienced an effective and informative learning process. Students believed the number of learning materials provided by the instructors is sufficient for their learning. This proves that students received enough learning materials support for learning which indeed has fulfilled the needs of their studies. These two points are interrelated to one another as students will be able to fulfill their study needs only if sufficient information and learning materials are given. Besides, students found the organization and navigation of the learning materials on the learning portal is well-designed as they were able to search for any respective information easily. Navigation is important and should be layout in the most simplistic way where all students can find and navigate through the portal even with a low level of digital literacy. According to Dutta \& Smita's (2020) qualitative research, they mentioned about students facing difficulties in using online platforms, have been a challenge for online learning. This issue has become a concern in which can be resolved by focusing on the online learning platform navigation.

The current study findings also indicate students' positive attitudes on the method of delivery for the learning materials. Students showed a high interest in the use of pre-recorded instructional videos in conveying knowledge and learning topics. The findings showed similarity to Osman's (2020) study where students demonstrated a positive perception of the quality and clarity of the recorded lectures and e-learning materials. It is surprising to achieve positive responses from students on the appropriateness of the learning content and flexibility in accessing the information for this study. This finding differed from the findings of Hyseni's (2020) case study which indicated students' negative attitudes on acquiring information due to the format of online learning. The reason for the different results might be due to the placement and selection of information and learning content. Sometimes it is important to not overcrowd the students with unrelated or too much extensive information on a learning topic. As discussed earlier, the method of delivering the learning content like the use of pre-recorded videos can provide an interesting and engaging experience to students.

Nevertheless, a minority of the students showed negative attitudes on the understanding of the information provided with minimal guidance from instructors. This study results do reflect on the findings from Ullah, Khan, \& Khan's (2017) quantitative study in which students indicated negative perception in understanding online learning materials without getting acquainted with appro- 
priate guidance. Some students displayed negative attitudes on being able to access the learning materials at a flexible time and location which is most likely due to the current locations they are situated at having limited access to internet services. Additionally, students were mentioning on maintaining their motivational level in watching long, monotonous videos. The finding reflects on the strategies and methods used in creating the videos to which provide students the intention to continue watching.

\subsubsection{Assessments}

The results of the current study show the strong positive attitudes of the student on having online assessments, as they are more effective and comfortable when compared with proctored exams. The findings were further supported by the students' explanation in the interviews. Most of the students who previously sit for proctored exams liked the implication of online projects or assignments due to the flexibility where students are given more freedom in searching for information for their write-ups. The open book exam mode has gotten the student's positive support since the model itself focuses on little to non-memorization of facts and concepts. The replacement of proctored exams with assignments, projects, or open book exam can be seen as other options to measure students learning on different topics. Students also mentioned the flexibility in taking the assessments online in which they can manage their tasks at their own pace. This finding shows similarity to Damşa, Nerland, \& Andreadakis's (2019) study on enabling students to organize and control their learning activities according to their own pace. Since the assessments are moved online, traveling to campus is no longer needed and the printing of assignments as hardcopy submissions are not required. This is a beneficial aspect which can save the traveling time to campus just to sit for an exam as well as to save up the cost of petrol and printing fees.

Apart from that, the current study specifies that most of the students like the well-organized information, instructions, and requirements of the online assessments. All the necessary details which are mandatory for the students' knowing shall be the key determinant on whether the instructions are delivered clearly. Nevertheless, it is interesting to achieve results showing a minority of students were not able to keep track and manage their assessments although they are well organized. Moreover, students believed the workload given is appropriate. The research findings did not show any results about students complaining about any extensive amount of workload as claimed in Aristovnik et al. (2020) and Rahiem (2020) studies. The excessive workload given by the instructors is might be related to the course management issues or instructors' incompetence during the instant switched to online learning which was also mentioned in Aristovnik et al. (2020) research findings. Also, students had a strong stance on the assignments given that are relevant and useful for their courses.

Some students expressed their preferences on the in-person presentation format for their assessments than online mode which were comprehended with 
Kamarianos et al. (2020) survey. The lack of physical presence while the artificial presence in the virtual work made students felt online presentations is unnatural. However, there is an interesting finding highlighted from the results data which was not discovered during the literature review. A student mentioned how online assignments are helpful and motivating as multiple small tasks are given throughout the semester. The division of the assignments into small tasks kept the student to stay motivated and constantly being efficient in completing the tasks.

\subsubsection{Online Communication}

In the current study, students displayed strong agreement on being able to reach out to the instructors online while receiving sufficient feedback and response as well as being able to communicate comfortably with the instructors. The swift responses from the instructors are important especially in learning to provide quality care for the students as well as to assist in providing problem resolution. Students also indicated their appreciation for the flexibility of online communication with peers and instructors via synchronous or asynchronous communication in their learning. This brings on to the next point on students' positive attitudes towards the use of live interactive platforms for synchronous learning and interaction like the Microsoft Teams and Zoom application. The results displayed similarities to Osman's (2020) study. Also, students specified that live streaming not only provides synchronous communication but also establishes a sense of community while interacting. These results findings comprehended with Srinivasan's (2020) study.

Some students even brought up different online communication applications which they utilized during their studies, like Emails, Facebook Messenger, WhatsApp, Discord, and Reddit. The diversity of communication applications can help students to learn and gain an external understanding of a learning topic. Students in the design and computing field claimed that they use Discord and Reddit to learn and seek other external advice in their learning topic. Instructors and educators should consider the establishment of Discord groups or the creation of subreddits for their students to join where other general participants who shared the common interest can further discuss, share, and exchange knowledge. Furthermore, students recommended the formation of online study groups among the students which can motivate each other during the learning process. The concern on the lack of use of the discussion forums had been highlighted by students during the interviews. The number of participants who take part in the discussion forums of the learning portal is ultimately low. This might be due to the shyness of an individual, the inactivity of the section which fails to prompt other students to participate, or even the cultural practice of students to remain silent in general discussion.

The findings of the current study do not correspond with the recent study of Gautam \& Gautam's (2020) which students felt that online classes are less effective due to the lack of face-to-face interaction. It is surprising to achieve a posi- 
tive result in this study as students believed online communication has made learning more effective than a face-to-face class. Moreover, the majority of the students showed positive attitudes towards the fact that online discussions have made them more interactive and participative than in a physical class. The ratings have proven an opposite finding when compared with Alawamleh, Al-Twait, \& Al-Saht's (2020) and Kamarianos et al.'s (2020) studies in which the majority of the students demonstrated negative attitudes due to the low level of communication.

\subsubsection{Technological Tools and Technical Support}

The results from the current study have highlighted students' high readings of students' positive attitude especially on the use of varieties of media and different digital tools which have made online learning more effective and exciting. Students' emphasis on the use of video technology in their learning has made learning adjustable to the learning needs. As shown in the results, recorded videos continue to deliver the learning content regardless of the switch to the online environment. Videos learning can help students to connect and understand a topic better with the composition of audio and visual effects, which students can repeat watching whenever desire. This brings on to the next point which students love the live streams of learning with peers and instructors. This method not only facilitates the learning needs but also opens up the opportunity for students to take part in the live discussion for real-time clarification, which corresponds to Aristovnik et al.'s (2020) survey study. Educators and instructors are still able to communicate and teach the students in a real-time session just like in a normal face-to-face class where all the intended teaching content can still be delivered.

Next, the engineering students specified the introduction of simulation learning for their courses. Students indicated a positive point of view and have become their preference to conduct an experiment or learning activity. The main reason was that simulations can exempt all the natural errors which occasionally will happen in a real live experimental situation in the lab. Simulations have proven to be an effective alternative to conduct hands-on learning while maintaining a quality learning experience whenever the physical application is unavailable. Also, students mentioned the use of an interactive software application call Kahoot. They liked the interactive and engaging way of learning through the use of Kahoot in which they can take part in game-like quizzes in a fun manner. As presented in the findings, Google Art \& Culture allows students to take virtual tours or field trips. Therefore, instructors and educators should consider and apply different types of learning applications to improve the learning experience of the students.

The current study reflects that students can adapt to the new teaching method with technology integration. This is an important aspect of online teaching and learning. It would be troublesome if students reject or show a lack of acceptance in the new way of delivering their learning in an online setting. Unlike Zia's 
(2020) quantitative study that discovered students had trouble in technology adaptability with the new teaching model. Nevertheless, students did raise the concern on poor internet connections would interfere with the online learning experience which comprehends with Dushkevych et al.'s (2020), Zhang et al.'s (2020), Mohmmed et al.'s (2020), Blizak et al.'s (2020) and Dutta \& Smita's (2020) research studies. This issue has been the main concern for many as every possible way of online course delivery relies on internet services.

On the technical support aspects, the results acquired from the current study show that students have received the desired support from their positive feedbacks. The results indicated similarities to Kamal et al.'s (2020) quantitative study. They will reach out to the instructors whenever there is trouble or error occurs in accessing the learning materials. The results clearly illustrated that the instructors are responsible and are efficient in providing relative support for their students. Besides, the student did claim on approaching the IT department if any issue encountered is beyond the capabilities of the instructors to resolve. However, a large number of students presented neutral attitudes in receiving help from the IT department of the institution they encounter problems related to the information system. The neutral attitude outcome might be related to students' uncertainty on the service from the IT as they never approach assistance from that department or the services provided are not satisfying.

\subsubsection{Online Learning Satisfaction}

Students' learning experience has reflected their online learning satisfaction in this current study. The students showed high satisfaction with the assessment methods used for their online learning. This is most likely due to the replacement of proctored exams with open book exams, projects, and assignments. Students are given more freedom in completing their assessments as compared to exams in classrooms in which they are being monitored throughout the sessions. Additionally, the student revealed that they would prefer online lessons than face-to-face classes if were given the option to chose for their courses as online learning provides more flexibility throughout their learning schedule. Students are given the flexibility to get prepared for every lesson as going to campus is completely restricted during this pandemic, thus saves up on the traveling time.

Besides, the current study shows the students' satisfaction with the learning materials, course activities, and the amount of workload assigned during their online learning. The results findings indicated a similarity to Hammouri and Abu-Shanab's (2018) study, mentioning how the quality of the information and relevancies of content can influence students' satisfaction. The convenience in accessing the learning materials and being able to complete their work fully online are some of the supporting reasons for their satisfactory claims for learning materials and activities. Furthermore, the introductions of simulation learning activities have attracted students' interest in learning even more. The implementation of simulation will be engaging and effective in students' learning with 
suitable learning content.

By putting all the findings together, they do correspond to Dziuban et al.'s (2015) and Cole, Shelley, \& Swartz's (2014) studies in which they highlighted that communication with students and technology used are important elements, determining an effective online learning experience. Therefore, the instructional approach and technology used by the instructors played a massive role in establishing a high online learning satisfaction among students. The results of this current study indicated students' high satisfaction with the interaction with their instructors. This has demonstrated instructors' effective contribution and care in managing and communicating with fellow students in meeting their study needs. As an instructor, it is important to have constant interaction and communication with the students in order to fulfill their learning requirements via synchronous and asynchronous communication.

Nevertheless, a number of students showed opposite results in online communication between classmates. The reason for this might be the cause of the unavailability or inconvenience to reach out to their peers due to lack of enthusiasm in learning or internet connection issues. This brings up another concern for the students, internet service, and connection. It has come to the point where internet connectivity is considered as the vital element that ensures students are being able to learn smooth in accessing all learning content and activities.

\subsection{Limitations of the Study}

The first limitation faced is the constant sampling number of participants from different faculty. As this research focused on the participants from different faculties of the University; mainly focusing on the STEM and non-STEM students, the number of participants might be inconstant for each sector due to the different number of student intake. The lack of a constant number of participants from each faculty might result in less accurate and insufficient data to represent and limit the ability to make a broader generalization from the result. Besides that, some respondents may have difficulty in understanding the items listed in the questionnaire which may lead to an incorrect response. The behavioral bias of individuals towards the rapid switch of the learning environment might interfere with their rational opinion on remote learning. The findings of this study were based on the assumption that the students responded honestly and interpreted the instruments as intended. Nevertheless, the research findings are still significant in helping educators to determine and improve the delivery of online learning to satisfy the need of students throughout the emergency remote learning.

\subsection{Recommendations}

\subsubsection{Practitioners}

Instructors and educators of other faculties and universities can implement the practices integrated from this research study. The different pedagogical approach and technological used presented in this research findings is applicable in 
online settings which can improve students' learning experiences. The results findings can use as a guide for other practitioners in tertiary education on how to approach and manage the learning materials, assessments, communications, technological tools as well as technical services.

\subsubsection{Policy Makers}

The policy makers of the institution should consider the opportunity to incorporate online learning technology for the whole education system where the technology may enhance the process of teaching and learning. Besides, policy makers of the institution should also take into consideration whether proctored exams are still suitable as learning assessments in the future, and should they be replaced with other assessment methods. From a broader perspective, the internet service providers should provide a more stable internet connection and services for the users which allows students to have a stable and uninterrupted online learning experience.

\subsubsection{Future Research}

This study is exploratory since there are limited empirical studies available for direct support. Future studies should replicate by using a different population and by controlling more variables. Future studies should focus on determining what combination of instructional pedagogy and technological tools is the most effective for what faculty of students in their online learning context. Therefore, future research should include a larger sample with varying levels and types of pedagogical approaches with the integration of technology in class.

\subsection{Conclusion}

The results of this study indicated that learning materials, assessments, communication, as well as technological tools and technical support had individual effects on students' attitudes. It was found that these elements were all related to students' course satisfaction. The interviews further indicated the dimensions of learner satisfaction corresponded with the four major areas of focus in this study. This study contributed to fields of practice by exploring students' attitudes toward online learning from different dimensions. The discovery of this current study can be considered for future study to construct a framework in which an optimal and comfortable online learning environment can be built and also fostering online learning effectiveness in a virtual setting.

Since educational researchers have been actively advocating for effective ways and methods in delivering meaningful learning during this pandemic, wellorganized learning materials and substantive communication among instructors

and students must be present in an online learning scenario. Online learning should also feature alternative assessment methods other than proctored exams. As Sandars et al. (2020) declared that online learning a collection of online learning modalities and technologies, instructors and practitioners should integrate relevant instructional pedagogies and strategies through the use of modern 
technologies to ensure not only the continuous delivery of learning courses but also for a better and effective learning experience.

\section{Acknowledgements}

This project paper is possible with the help of many people. First, I would like to thank my course supervisor, Madam Sislady Melinda Rosius, for supervising my project paper and for giving me complete flexibility, assistance, and guidance to make this project come true. I would like to thank Prof Dr. John Arul Phillips for all his mentoring and guidance in my research and for helping me to develop insights into the field of education. Finally, I would like to thank my parents and close friends for all their support and love which have kept me going through the ups and downs of both my study and of my life. Thank you.

\section{Conflicts of Interest}

The author declares no conflicts of interest regarding the publication of this paper.

\section{References}

Adnan, M., \& Anwar, K. (2020). Online Learning Amid the COVID-19 Pandemic: Students Perspectives. Journal of Pedagogical Research, 2, 45-51. https://doi.org/10.33902/JPSP.\%202020261309

Alawamleh, M., Al-Twait, L. M., \& Al-Saht, G. R. (2020). The Effect of Online Learning on Communication between Instructors and Students during COVID-19 Pandemic. Asian Education and Development Studies, Ahead-of-Print. https://doi.org/10.1108/AEDS-06-2020-0131

Alipio, M. (2020). Education during COVID-19 Era: Are learners in a Less-Economically Developed Country Ready for E-Learning? https://ideas.repec.org/p/zbw/esrepo/216098.html

Al-Jedaiah, M. (2020). Knowledge Management and E-Learning Effectiveness: Empirical Evidence from Jordanian Higher Education Institutions. International Journal of Emerging Technologies in Learning, 15, 50-62. https://www.learntechlib.org/p/217134/ https://doi.org/10.3991/ijet.v15i05.11653

Alvarez Jr., A. (2020). The Phenomenon of Learning at a Distance through Emergency Remote Teaching Amidst the Pandemic Crisis. Asian Journal of Distance Education, $15,144-153$.

Aristovnik, A., Keržič, D., Ravšelj, D., Tomaževič, N., \& Umek, L. (2020). Impacts of the COVID-19 Pandemic on Life of Higher Education Students: A Global Perspective. Sustainability, 12, 8438. https://doi.org/10.20944/preprints202008.0246.v1

Basilaia, G., Dgebuadze, M., Kantaria, M., \& Chokhonelidze, G. (2020). Replacing the Classic Learning form at Universities as an Immediate Response to the COVID-19 Virus Infection in Georgia. International Journal for Research in Applied Science and Engineering Technology, 8, 101-108. https://doi.org/10.22214/ijraset.2020.3021

Basilaia, G., \& Kvavadze, D. (2020). Transition to Online Education in Schools during a SARS-CoV-2 Coronavirus (COVID-19) Pandemic in Georgia. Pedagogical Research, 5, Article No. em0060. https://doi.org/10.29333/pr/7937

Blizak, D., Blizak, S., Bouchenak, O., \& Yahiaoui, K. (2020). Students’ Perceptions Re- 
garding the Abrupt Transition to Online Learning During the COVID-19 Pandemic: Case of Faculty of Chemistry and Hydrocarbons at the University of BoumerdesAlgeria. Journal of Chemical Education, 97, 2466-2471. https://doi.org/10.1021/acs.jchemed.0c00668

Bao, W. (2020). COVID-19 and Online Teaching in Higher Education: A Case Study of Peking University. Human Behavior and Emerging Technologies, 2, 113-115. https://doi.org/10.1002/hbe2.191

Crawford, J., Butler-Henderson, K., Rudolph, J., Malkawi, B., Glowatz, M., Burton, R., Magni, P. A., \& Lam, S. (2020). COVID-19: 20 Countries' Higher Education IntraPeriod Digital Pedagogy Response. Journal of Applied Learning and Teaching, 3, 9-28. https://doi.org/10.37074/jalt.2020.3.1.7

Clark, T. M., Callam, C. S., Paul, N. M., Stoltzfus, M. W., \& Turner, D. (2020). Testing in the Time of COVID-19: A Sudden Transition to Unproctored Online Exams. Journal of Chemical Education, 97, 3413-3417. https://doi.org/10.1021/acs.jchemed.0c00546

Cole, M. T., Shelley, D. J., \& Swartz, L. B. (2014). Online Instruction, E-Learning, and Student Satisfaction: A Three Year Study. The International Review of Research in Open and Distributed Learning, 15, 111-131.

Damşa, C., Nerland, M., \& Andreadakis, Z. E. (2019). An Ecological Perspective on Learner-Constructed Learning Spaces. British Journal of Educational Technology, 50, 2075-2089. https://doi.org/10.1111/bjet.12855

Degago, A. T., \& Kaino, L. M. (2015). Towards Student-Centered Conceptions of Teaching: The Case of Four Ethiopian Universities. Teaching in Higher Education, 20, $493-$ 505. https://doi.org/10.1080/13562517.2015.1020779

Dziuban, C., Moskal, P., Hermsdorfer, A., DeCantis, G., Norberg, A., \& Bradford, G. (2015). A Deconstruction of Blended Learning. The 11th Annual Sloan-C Blended Learning Conference and Workshop, Denver, 7-8 July 2015.

Dushkevych, M., Barabashchuk, H., \& Hutsuliak, N. (2020). Peculiarities of Student Distance Learning in Emergency Situation Condition. Revista Romaneasca Pentru Educatie Multidimensionala, 12, 71-77. https://doi.org/10.18662/rrem/12.1sup2/248

Dutta, S., \& Smita, M. K. (2020). The Impact of COVID-19 Pandemic on Tertiary Education in Bangladesh: Students' Perspectives. Open Journal of Social Sciences, 8, 53-68. https://doi.org/10.4236/jss.2020.89004

Fayer, L. (2017). A Multi-Case Study of Student Perceptions of Instructor-Created Videos in Online Courses. International Journal for Scholarship of Technology Enhanced Learning, 1, 67-90.

Gedera, D., Williams, J., \& Wright, N. (2015). Identifying Factors Influencing Students' Motivation and Engagement in Online Courses. In C. Koh (Eds.), Motivation, Leadership and Curriculum Design: Engaging the Net Generation and 21st Century Learners (pp. 13-23). Singapore: Springer. https://doi.org/10.1007/978-981-287-230-2 2

Giordano, A. N., \& Christopher, C. R. (2020). Repurposing Best Teaching Practices for Remote Learning Environments: Chemistry in the News and Oral Examinations during COVID-19. Journal of Chemical Education, 97, 2815-2818.

https://doi.org/10.1021/acs.jchemed.0c00753

Gautam, D. K., \& Gautam, P. K. (2020). Transition to Online Higher Education during COVID-19 Pandemic: Turmoil and Way Forward to Developing Country-Nepal. https://doi.org/10.21203/rs.3.rs-59206/v1

Gupta, D. R. (2018). A Comparative Study of Online and Face to Face Education for Learners and Teachers in Management.

http://shodhganga.inflibnet.ac.in/handle/10603/257304 
Hammouri, Q., \& Abu-Shanab, E. (2018). Exploring Factors Affecting Users' Satisfaction toward E-Learning Systems. International Journal of Information and Communication Technology Education, 14, 44-57. https://doi.org/10.4018/IJICTE.2018010104

Hyseni, D. Z. (2020). The Impact of COVID-19, School Closure, and Social Isolation on Gifted Students' Wellbeing and Attitudes toward Remote (Online) Learning.

Hodges, C., Moore, S., Lockee, B., Trust, T., \& Bond, A. (2020). The Difference between Emergency Remote Teaching and Online Learning. https://medicine.hofstra.edu/pdf/faculty/facdev/facdev-article.pdf

Jacob, O. N., Abigeal, I., \& Lydia, A. E. (2020). Impact of COVID-19 on the Higher Institutions Development in Nigeria. Electronic Research Journal of Social Sciences and Humanities, 2, 126-135.

http://www.eresearchjournal.com/wp-content/uploads/2020/04/0.-Impact-of-COVID. pdf

Jeong, H., \& Hmelo-Silver, C. E. (2016). Seven Affordances of Computer-Supported Collaborative Learning: How to Support Collaborative Learning? How Can Technologies Help? Educational Psychologist, 51, 247-265.

https://doi.org/10.1080/00461520.2016.1158654

Joseph, P. M., \& Mkulu, D. G. (2020). Online Classes during COVID-19 Pandemic in Higher Learning Institutions in Africa. Global Research in Higher Education, 3, 1-21. https://doi.org/10.22158/grhe.v3n3p1

Kamal, A. A., Mohd, N., Truna, L., Sabri, M., \& Junaini, S. N. (2020). Transitioning to Online Learning during COVID-19 Pandemic: Case Study of a Pre-University Centre in Malaysia. International Journal of Advanced Computer Science and Applications, 11, 217-223. https://dx.doi.org/10.14569/I]ACSA.2020.0110628

Kamarianos, I., Adamopoulou, A., Lambropoulos, H., \& Stamelos, G. (2020). Towards and Understanding of University Students' Response in Times of Pandemic Crisis (COVID-19). European Journal of Education Studies, 7, 20-40. https://doi.org/10.46827/ejes.v7i7.3149

Kaufmann, R., Sellnow, D. D., \& Frisby, B. N. (2016). The Development and Validation of the Online Learning Climate Scale (OLCS). Communication Education, 65, 307-321. https://doi.org/10.1080/03634523.2015.1101778

Kearns, L. R. (2016). The Experience of Teaching Online and Its Impact on Faculty Innovation across Delivery Methods. The Internet and Higher Education, 31, 71-78. https://www.learntechlib.org/p/199113/ https://doi.org/10.1016/j.iheduc.2016.06.005

Kelly, S., \& Claus, C. J. (2015). Practicing Nonverbal Awareness in the Asynchronous Online Classroom. Communication Teacher, 29, 37-41. https://doi.org/10.1080/17404622.2014.985597

Kim, J., Song, H., \& Luo, W. (2016). Broadening the Understanding of Social Presence: Implications and Contributions to the Mediated Communication and Online Education. Computers in Human Behavior, 65, 672-679.

https://doi.org/10.1016/j.chb.2016.07.009

Lukong, T., Tombari, C., Mbome, B., Ankinibom, C., Fru, P., Atong, H. et al. (2020). Psychological Implications of COVID-19 on Students Learning Outcome at the University of Buea, Cameroon. American Research Journal of Humanities \& Social Science, 3, 1-14. https://www.arjhss.com/wp-content/uploads/2020/08/A380114.pdf

Mailizar, M., Almanthari, A., Maulina, S., \& Bruce, S. (2020). Secondary School Mathematics Teachers' Views on E-learning Implementation Barriers during the COVID-19 Pandemic: The Case of Indonesia. Eurasia Journal of Mathematics, Science and Tech- 
nology Education, 16, em1860. https://doi.org/10.29333/ejmste/8240

Mohmmed, A. O., Khidhir, B. A., Nazeer, A., \& Vijayan, V. J. (2020). Emergency Remote Teaching during Coronavirus Pandemic: The Current Trend and Future Directive at Middle East College Oman. Innovative Infrastructure Solutions, 5, Article No. 72. https://doi.org/10.1007/s41062-020-00326-7

Mulyanti, B., Purnama, W., \& Pawinanto, R. E. (2020). Distance Learning in Vocational High Schools during the COVID-19 Pandemic in West Java Province, Indonesia. Indonesian Journal of Science and Technology, 5, 271-282.

Munoz, A., \& Mackay, J. (2019). An Online Testing Design Choice Typology towards Cheating Threat Minimisation. Journal of University Teaching \& Learning Practice, 16, Article No. 5. https://ro.uow.edu.au/jutlp/vol16/iss3/5/

Murphy, M. P. A. (2020). COVID-19 and Emergency ELearning: Consequences of the Securitization of Higher Education for Post-Pandemic Pedagogy. Contemporary Security Policy, 41, 492-505.

Nguyen, T. (2015). The Effectiveness of Online Learning: Beyond No Significant Difference and Future Horizons. MERLOT Journal of Online Learning and Teaching, 11, 309-319.

Northey, G., Bucic, T., Chylinski, M., \& Govind, R. (2015). Increasing Student Engagement Using Asynchronous Learning. Journal of Marketing Education, 37, 171-180. https://doi.org/10.1177\%2F0273475315589814

Osman, M. (2020). Global Impact of COVID-19 on Education Systems: The Emergency Remote Teaching at Sultan Qaboos University. Journal of Education for Teaching, 46, 463-471. https://doi.org/10.1080/02607476.2020.1802583

Onyemo, E. M. (2019). Integration of Emerging Technologies in Teaching and Learning Process in Nigeria: The Challenges. Central Asian Journal of Mathematical Theory and Computer Sciences, 1, 35-39.

Panigrahi, R., Srivastava, P. R., \& Sharma, D. (2018). Online Learning: Adoption, Continuance, and Learning Outcome-A Review of Literature. International Journal of Information Management, 43, 1-14. https://doi.org/10.1016/j.ijinfomgt.2018.05.005

Esterhuyse, M. P., Scholtz, B. M., \& Venter, D. (2016). Intention to Use and Satisfaction of e-Learning for Training in the Corporate Context. Interdisciplinary Journal of Information, Knowledge, and Management, 11, 347-365. https://doi.org/10.28945/3610

Pickering, J. D., \& Swinnerton, B. J. (2019). Exploring the Dimensions of Medical Student Engagement with Technology-Enhanced Learning Resources and Assessing the Impact on Assessment Outcomes. Anatomical Sciences Education, 12, 117-128. https://doi.org/10.1002/ase.1810

Rahiem, M. D. H. (2020). The Emergency Remote Learning Experience of University Students in Indonesia amidst the COVID-19 Crisis. International Journal of Learning, Teaching and Educational Research, 19, 1-26. https://doi.org/10.26803/ijlter.19.6.1

Rapanta, C., Botturi, L., Goodyear, P., Guàrdia, L., \& Koole, M. (2020). Online University Teaching During and After the COVID-19 Crisis: Refocusing Teacher Presence and Learning Activity. Postdigital Science and Education, 2, 923-945. https://doi.org/10.1007/s42438-020-00155-y

Richardson, J. C., \& Swan, K. (2019). Examining Social Presence in Online Courses in Relation to Students' Perceived Learning and Satisfaction. Online Learning, 7, 68-88.

Sandars, J., Correia, R., Dankbaar, M., de Jong, P., Goh, P. S., Hege, I., Masters, K., Oh, S.-Y., Patel, R., Premkumar, K., Webb, A., \& Pusic, M. (2020). Twelve Tips for Rapidly Migrating to Online Learning during the COVID-19 Pandemic. MedEdPublish, 9, 82. https://doi.org/10.15694/mep.2020.000082.1 
Singh, R. N., \& Hurley, D. (2017). The Effectiveness of Teaching-Learning Process in Online Education as Perceived by University Faculty and Instructional Technology Professionals. Journal of Teaching and Learning with Technology, 6, 65-75. https://doi.org/10.14434/jotlt.v6.n1.19528

Srinivasan, D. K. (2020). Medical Students' Perceptions and an Anatomy Teacher's Personal Experience Using an E-Learning Platform for Tutorials during the Covid-19 Crisis. Anatomical Sciences Education, 13, 318-319. https://doi.org/10.1002/ase.1970

Stevens, R. (2015). Role-Play and Student Engagement: Reflections from the Classroom. Teaching in Higher Education, 20, 481-492.

https://doi.org/10.1080/13562517.2015.1020778

Sun, J. (2016). Multi-Dimensional Alignment between Online Instruction and Course Technology: A Learner-Centered Perspective. Computers \& Education, 101, 102-114. https://doi.org/10.1016/j.compedu.2016.06.003

Teo, T. S. H., Kim, S. L., \& Jiang L. (2018). E-Learning Implementation in South Korea: Integrating Effectiveness and Legitimacy Perspectives. Information Systems Frontiers, 22, 511-528. https://doi.org/10.1007/s10796-018-9874-3

Ullah, O., Khan, W., \& Khan, A. (2017). Students' Attitude towards Online Learning at Tertiary Level. PUTAJ-Humanities and Social Sciences, 25, 63-82.

Weeden, K., \& Cornwell, B. (2020). The Small-World Network of College Classes: Implications for Epidemic Spread on a University Campus. Sociological Science, 7, 222-241. https://doi.org/10.15195/v7.a9

Woodworth, J. L., Raymond, M. E., Chirbas, K., Gonzalez, M., Negassi, Y., Snow, W., \& Van Donge, C. (2015). Online Charter School Study 2015. Stanford, CA: Center for Research on Educational Outcomes. https://credo.stanford.edu/sites/g/files/sbiybj6481/f/online charter study final.pdf

Wu, Z. (2020). How a Top Chinese University Is Responding to Coronavirus. World Economic Forum.

https://www.weforum.org/agenda/2020/03/coronavirus-china-the-challenges-of-online -learning-for-universities/

Zia, A. (2020). Exploring Factors Influencing Online Classes Due to Social Distancing in COVID-19 Pandemic: A Business Students Perspective. The International Journal of Information and Learning Technology, 37, 197-211. https://doi.org/10.1108/IJLT-05-2020-0089

Zhang, W., Wang, Y., Yang, L., \& Wang, C. (2020). Suspending Classes without Stopping Learning: China's Education Emergency Management Policy in the COVID-19 Outbreak. Journal of Risk and Financial Management, 13, Article No. 55. https://doi.org/10.3390/jrfm13030055

Zhong, R. (2020). The Coronavirus Exposes Education's Digital Divide. https://www.nytimes.com/2020/03/17/technology/china-schools-coronavirus.html 